\title{
ИЗМЕЪУ МОБИЛНОСТИ И МИГРАЦИЈЕ: ПРИКРИВЕНИ ОДЛИВ МОЗГОВА У СРБИЈИ ${ }^{2}$
}

Апстракт: Covid-19 пандемија је усмерила „рефлекторе” на информационо комуникационе технологије (скр. ИКТ) и узроковала убрзање дигиталне трансформације светске економије и друштва. Нова дигитална радна снага има две главне карактеристике: креирање нових послова и растућу мобилост. Међутим, смањивање дигиталне радне снаге (услед старења популације) и недовољан број радника са високим нивоом дигиталних вештина, поготово у ЕУ, чини емиграцију још увек актуелним процесом. Овај рад анализира специфични облик емиграционог процеса, назван скривени одлив мозгова, који је последица како повећане употребе ИКТ технологија (услед дигиталне трансформације) тако и растућег недостатка радне снаге са високим нивоом дигиталних вештина. Прикривени одлив мозгова представља виртуелну емиграцију (у смислу емиграције мозгова и вештина) високообразоване (високостручне) информатичке радне снаге која захваљујући, пре свега интернету, ради за предузећа у страном власништву, а притом живи у својој земљи. За анализу прикривеног одлива мозгова интервјуисано је 8 младих (22-29 година) високообразованих програмера који живе у Србији, а раде за предузећа у страном власништву. Полуструктурисани интервју се показао као погодан метод за прикупљање података потребних за разумевање ставова и мотива испитаника везаних за емиграцију и рад у страним компанијама. Анализа је осветлила неколико интересантних разлога који стоје иза феномена скривеног одлива мозгова и они могу бити употребљени као смернице за будућа истраживања. Изненађујуће, млади програмери у Србији немају жељу да емигрирају, будући да су окружени блиским људима и имају квалитетне услове за рад и живот. Са друге стране, пропорционално смањење ове (дигиталне) радне снаге на домаћем тржишту, као нова форма емиграције, може да доведе до значајних поремећаја на локалном тржишту радне снаге.

Кључне речи: прикривени одлив мозгова, одлив мозгова, ИКТ, дигитална трансформација, Србија.

\footnotetext{
1 bmatijevic@idn.org.rs

2 Рад је написан у оквиру Програма истраживања Института друштвених наука за 2020. годину који подржава Министарство просвете, науке и технолошког развоја.
} 


\section{Увод}

У савременом друштву, којег карактерише дигитална трансформација, разматра се проблем одлива мозгова. Овај облик представља виртуелну радну миграцију коју називамо прикривеним одливом мозгова јер је продукт интензивног развоја и усвајања информационо комуникационих технологија. Сматрамо да је Србија суочена са овим феноменом из најмање два разлога: земља је у раној фази дигиталне трансформације, друго, земља је за коју су и даље карактеристичне економске емиграције и процес одлива мозгова.

Предмет рада је анализа прикривеног одлива мозгова кроз пример младих програмера који раде у иностраним фирмама, а живе у Србији. Циљ рада је разумевање и уочавање главних одлика прикривеног одлива мозгова, као и уочавање могућих последица његовог занемаривања. Услед избора методологије, рад нема за циљ да генерализује резултате, већ да подстакне одређена питања која би могла да покрену академску (али и ширу) заједницу за даље бављење овом темом.

\section{Дефинисање и сагледавање прикривеног одлива мозгова у Србији}

Процес глобализације омогућава неометану међународну размену робе, услуга и људи, те мобилност представља једну од основних одлика савременог доба. Растућој мобилности доприноси и процес дигиталне трансформације. Међутим, постојећа економска неједнакост, укључујући и дигиталну поделу, присутна на глобалном нивоу важан је разлог због којег је, поред растуће мобилности, и даље приметна емиграција.

За земље попут Србије, и даље је каракеристичан проблем одласка високообразованих лица и стручњака. Имиграционо радно способно становништво, доприносећи развоју земаља првог света, оставља многобројне последице по земље света из којих су емигрирали. Овај проблем, у зависности од образовне и професионалне структуре емиграната, утиче на понуду квалитетне радне снаге, на продуктивност и иновативност земље (ИОМ, 2012, према Марјановић, 2015). Додатно, услед развоја информационо комуникационих технологија (скр. и у даљем тексту ИКТ), појављују се нови облици емиграције, које омогућава постојећи развој 
технологије. Један од таквих облика, прикривени одлив мозгова, у овом раду анализирамо управо из перспективе земље „одласка”, односно у којој се одвија процес емиграције.

Под прикривеним одливом мозгова подразумева се виртуелна емиграција високообразоване радне снаге која, пре свега, захваљујући интернету чини да радно способно становништво не емигрира физички, али је de facto радна снага која је виртуелно емигрирала. У раду се прикривени одлив мозгова посматра кроз запослене младе програмере који живе у Србији, али раде за предузећа у иностраном власништву.

Прва карактеристика прикривеног одлива мозгова јесте што га сматрамо продуктом развоја и утицаја ИКТ-а. Сматрамо да технологија одражава већ постојеће друштвене трендове и појаве, дајући им понекад и нови облик. Тако, иако није спорно да су миграције постојале и пре настанка и развоја ИКТ, оне сада добијају нове облике који коегзистирају са традиционалним.

Поменули смо да се Србија сматра традиционално земљом економске емиграције, као и земљом суоченом са феноменом одлива мозгова ${ }^{3}$.

„Иако је прикупљање података и извештавање о имиграцији значајно побољшано од 2010. године, када је почео да се припрема Миграциони профил Републике Србије, званични подаци о емиграцији за Републику Србију ипак не постоје“ (Марјановић, 2015: 7-8). Из наведеног разлога се, „процене и информације најчешће заснивају на подацима главних земаља пријема и информација о укупном становништву и природном прираштају у периоду између пописа становништва 2002. и 2011. године, указују да је, на годишњем нивоу нето миграциони губитак износио приближно 15.000

3 Термин одлив мозгова, повезан је са феноменом националних економија са једне, и стварањем глобалног економског и научног развоја са друге стране (Деспић, 2015: 16). Но, овај термин се не сматра примереним, „јер ствара антагонизам између високообразованих и осталих емиграната, као и између високообразованих лица која су отишла...и оних који су остали у земљи“ (Рашевић, 2016: 44). Како истиче Рашевић, „употреба ових термина је потврда да је ова тема у српском друштву болна и да се на емотивној основи увиђају пре свега негативне последице одласка на рад-боравак у иностранство лица са највишим образовањем“ (Рашевић, 2016: 45) због чега се у раду и опредељујемо за коришћење овог термина. 
становника“ (Влада Републике Србије, 2014 према Марјановић, 2015: 8). Буран период за Србију, имајући у виду санкције од стране НАТО, хиперинфлацију, пад привредних активности, реструктурирање државних предузећа, бомбардовање су били значајни чиниоци утицаја на емиграцију. „И анализа издатих имигрантских виза висококвалификованим особама из Србије указује на то да је одлив мозгова појачан током последње две деценије двадесетог века“, где је „међу висококвалификованима којима је одобрена имиграциона виза за САД и Канаду, на крају последње декаде двадесетог века, највише било оних са стручним и техничким специјалностима (научника, инжењера и математичара)“ (Марјановић, 2015: 11).

Овде је значајно поменути и резултате истраживања „Млади у Србији 2015” (Томановић, Станојевић, 2015). Подаци указују да је 30,8\% младих изјавило да не жели да се одсели, петина $(20,8 \%)$ да је њихова жеља за одсељењем веома јака, а по четвртина да је жеља средња $(23,9 \%)$ или слаба $(23,8 \%)$ (Томановић, Станојевић, 2015: 92). Такође, мотивација младих за евентуалну емиграцију скоро је у потпуности економска (81,9\%): побољшање животног стандарда (65,2\%), лакше запослење $(16,6 \%)$, док су најпожељније земље дестинације за емиграцију земље ЕУ (за 22,8\% младих) (Томановић, Станојевић, 2015: 92).

Имајући на уму ситуацију у Србији у веза са емиграцијом, као и за процес одлива мозгова, као и видљиву мотивацију младих да емигрирају јасно је да се проблем прикривеног одлива мозгова само надовезује на постојеће стање.

Друга карактеристика прикривеног одлива мозгова је повезаност са раном фазом процеса дигиталне трансформације (попут приступа и употребе интернета, школовања ИКТ кадра, доласка иностраних компанија). Иако неразвијен, ипак започет процес дигиталне трансформације у Србији отвара доста простора за отварање „огранака“ иностраних фирми на њеном подручју. Србија се сматра погодном дестинацијом за стационирање иностраних фирми, пре свега, јер има квалитетну, а уједно и јефтину радну снагу, што за последицу има формирање прикривеног одлива мозгова. 
Показатељи који иду у прилог тези да је дигитална трансформација Србије у раној фази, а тиме ствара и повољне услове за прикривени одлив мозгова видљиви су у многим друштвеним аспектима окружења, али првенствено у самом ИКТ сектору будући да је не само водећи у погледу информационих технологија, већ и најбољи показатељ утицаја дигиталне трансформације на пословање, конкурентност и економски развој.

Према извештају ICT in Serbia: At a Glance (2020), број предузећа 2018. године порастао је за 38\% у односу на 2011. годину, док је број запослених порастао за 91,8\% (Шолаја, Матијевић, 2020: 68).

На основу наведеног, у Србији је приметан развој ИТ сектора. Процењује се да се у Србији годишње „оснива око 200 информатичких предузећа али да су највећи број новооснованих програмерске фирме, које су усмерене на витално и ликвидно интернационално информатичко тржиште“ (Шолаја, Матијевић, 2018: 48). Иста је ситуација и са школованим програмерима - од укупног броја запослених у ИТ сектору у 2016. години (са 21.514 запослених), њих 10.068 ради у фирмама са иностраним власништвом (Шолаја, Матијевић, 2018: 48). Било би добро да се процене економске последице тога што се млади у овом случају школују да раде за стране фирме и инострана тржишта, као и последице „јефтинијег извоза” квалитетне радне снаге, а увоза „скупих“ технолошких решења.

\section{Приказ методологије истраживања}

За потребе овога рада, примењена је квалитативна методологија где се као метод за прикупљање података користио полуструктурисани интервју. Подаци добијени квалитативним приступом су прикупљени примарно за потребе овог истраживања, зарад бољег разумевања и сагледавања проучаване друштвене појаве. Ипак, сматрамо да би комплементарна употреба квантитативне и квалитативне методологије била идеална за потпуно сагледавање прикривеног одлива мозгова у Србији.

У раду је коришћен намерни (непробабилистички) узорак, с обзиром на то да су испитаници бирани по личном уверењу као типични или репрезентативни за дати основни скуп. Како циљ рада није доношење 
закључака и генерализација о овој појави, наведени тип узорка омогућава разумевање тренда, а додатно је прикладан и у пилотским истраживањима.

Узорак чини осам испитаника, интервјуисаних у периоду од децембра до марта 2019. године. Испитаници се сматрају представницима прикривеног одлива мозгова, јер испуњавају следеће услове:

- високообразовани су, односно завршили су неки од релевантних техничких факултета (са ИКТ смеровима);

- запослени су као програмери/ ИТ стручњаци у иностраној фирми (гледано по оснивачу) у оквиру ИТ делатности иако већим делом „раде од куће”;

- припадници су млађе старосне категорије (15-29 година), с том разликом што је категорија сужена на 22-29 година с обзиром да је уједно услов и да је испитаник високообразован;

- живе у Србији.

С обзиром на то да је циљ рада разумевање прикривеног одлива мозгова и уочавање његових главних одлика, од многих постављених представићемо следећа истраживачка питања:

- Који су мотиви и аспирације младих програмера за рад у фирми која је у иностраном власништву?

- Какав је њихов став о запослењу у фирмама које су у домаћем власништву?

- Какав је њихов став према емиграцији генерално, а какав по питању личног одласка?

- Које су главне одлике прикривеног одлива мозгова? Да ли се могу уочити одређене предности и недостаци?

- Да ли се могу уочити одређене последице прикривеног одлива мозгова по Србију? (Уколико да, које су то последице?)

\section{Анализа резултата: ставови, мотиви и аспирације младих програмера}

Занимљиво опажање је да су сви навели да су прилично задовољни стеченим знањем на техничким факултетима и да ниједан испитаник није размишљао о томе да упише факултет у иностранству. Испитивани млади програмери сматрају да је у Србији присутан веома висок квалитет 
образовања. Поједини чак сматрају да је и квалитетнији него што је у иностранству.

Мотивисани су да се баве овим послом јер су склони природним наукама, те је решавање логичких проблема нешто што им причињава задовољство. Услови који су потребни да би испитивани млади програмери осећали да су задовољни својим послом јесу делом материјалне (висока плата), а делом нематеријалне природе (аутономија на послу, осећај припадности одређеној корпоративној култури). Додатно, добробити које програмери перципирају да (лично) имају од рада у иностраној фирми поклапају се са жељеним условима на послу који су потребни да би били задовољни њиме, а такође су делом материјалне (висока плата), а делом нематеријалне природе (аутономија, лично усавршавање и сл.). Сви испитаници, без обзира на то што су запослени у различитим (иностраним) фирмама, задовољни су висином плате и никада нису имали проблем са њеним кашњењем. Такође, сви су сагласни да су тренутно запослени на месту погодном за стицање додатног искуства, усавршавање и примену већ наученог.

И1: Фирма у којој радим ми пружа пре свега слободу да експериментишем, да будем креативан, проналазим решења као и да имплементирам та решења. Такође бенефити у смислу да ми омогућују да радим на себи, рад од куће, добра опрема, “слатки петак” у смислу могућности узимања слободног дана, поред викенда и тако... (мушко, ЕТФ, 26, Београд)

Да би се утврдило који су то мотиви и аспирације младих програмера за рад у иностраној фирми, потребно је рећи да је установљено да је код младих програмера присутна и потреба са самоактуализацијом. Могући разлог је што су код ове групе људи задовољене „основне хијерархијске потребе“ попут добре и редовне плате, затим и одређеног степена аутономије на послу, те млади програмери имају могућност да се усмере на исказивање властитих потенцијала. Квалитетни услови рада, услови за стицање знања, могућност похађања додатних курсева које им фирма пружа, неки су од мотива младих програмера за рад у иностраној фирми. 
Да је присутна потреба за додатним усавршавањем, потврђује и податак да седам од осам испитаника похађа одређене курсеве. Делом су то курсеви обезбеђени од стране фирме у којој су запослени, али су и онлајн курсеви које сами проналазе, купују и похађају путем интерента.

И1: „Фирма у којој радим константно организује разноразне обуке, тренинге и курсеве. Завршила сам три нивоа немачког језика, курсеве АБАП програмирања, положила сертификате за консултанта и одмах кренула да учим и радим директно на пројекту.“ (женско, ФОН, 24, Београд)

И2: „Не идем физички, али похађам два online курса.“ (мушко, ЕТФ, 26, Београд)

Поред личних, сагласни су да постоје и одређене добробити које шира заједница има од тога што они и њихове колеге раде у оквиру иностране фирме. Један испитаник је навео да не само да српско друштво има добробити већ су оне присутне и на ширем, глобалном нивоу.

И1: „Главна добробит је зато што постоји могућност запошљавања младих, који су се образовали, односно стекли високо образовање, који иако траже, не могу да нађу квалитетне послове.“ (женско, ЕТФ, 27, Београд)

И2: „За Србију је добро јер има прилив новца. Па и у том случају, порези који се плаћају, доприноси. Такође, пословне посете запослених из Швајцарске, који често долазе са породицом као што ми одлазимо код њих." (мушко, ЕТФ, 26, Београд)

С обзиром на то да су задовољни својим послом у иностраној фирми, поставља се питање какав је њихов став о раду у домаћим фирмама?

Испитаници познају мали број колега са посла и факултета који раде у домаћим фирмама (које су усмерене на домаће тржиште) и сви мисле да је то што су се њихове колеге определиле да раде у домаћој фирми индивидуална одлука. Међутим, ставови им се разликују када је реч о личном запослењу у домаћим фирмама. Поједини испитивани млади програмери не би правили разлику између домаће и иностране фирме уколико би обе омогућиле пресудне факторе: добру плату и погодне услове за рад. С друге стране, једна испитаница би се определила за домаћу, док би друга ипак изабрала инострану фирму. 
И1: „Изабрала бих домаћу фирму усмерену на домаће тржиште, због познавања менталитета људи, лакше комуникације (матерњи језик) и мањег стреса. Мирније бих радила због присуства породице и пријатеља са којима сам одрасла. Мир, спокој и разумевање који пружа држава одакле сте, не могу да се мере ни са једном другом земљом и фирмом.“ (женско, 24, ФОН, Београд)

И2: „Тренутно бих изабрала инострану, првенствено због негативних историјских догађаја. Мислим да су услови ипак у реалности, између иностране и домаће фирме, небо и земља. На пример када имаш породиљско у иностраној фирми, заштићен си. Конкретно америчка фирма те не ограничава до када ти стриктно траје одсуство, док је ситуација другачија у домаћој фирми. Када си на породиљском, код нас немају толико разумевања. Када причамо о ИТ фирмама делује као да је све на истом нивоу, али ипак није. Ипак се види разлика." (женско, 25, ФОН, Београд)

Када је реч о истраживачком питању о томе какав је став младих програмера према емиграцији у иностранство погодна околност, по Србију, је то што млади програмери немају жељу за емиграцијом. Разлог је, како испитаници сматрају, тај што су у Србији окружени блиским људима, а уједно имају квалитетне услове за рад. Код неких испитаника постоји заинтересованост (али не и планирање) за привремени одлазак у иностранство како би евентуално стекли нова искуства.

И1: „Осим привремених пројеката на које бих била слата од стране свог менаџера или туристичког обиласка, није ми падало на памет да идем у иностранство. Овде сам створила све што ми треба." (женско, ФОН, 24, Београд)

И2: „Паа...(размишља)... отишла бих, можда, јер бих волела да додатно усавршим страни језик, да видим како је то живети негде другде, стекнем нова искуства и познанства.“ (женско, 27, ЕТФ, Београд)

Иако испитаници нису исказали претерану жељу за емиграцијом, сваки од њих познаје одређен број колега са посла и факултета (у просеку сваки испитаник познаје девет колега) који су се определили да оду у иностранство. Као што мисле да је индивидуална одлука (произашла из различитих жеља и околности) оних који су одлучили да раде у домаћој 
фирми, тако мисле да су индивидуални разлози пресудни за то због чега су се одређене колеге определиле да емигрирају.

Њихово тумачење разлога због чега постоји тренд одлива високообразованих, пружа један занимљив и поприлично детаљан поглед на стање ствари.

И1: „Људи воле паре.“

Мислиш да је главни мотив новац?

И1: „Тако је. Други мотив је то што људи воле извесност, а у Србији је велика неизвесност. Пао ми је на памет и трећи мотив а то је сам тренд одласка из Србије и то је популарно у смислу “ако си паметан шта радиш овде".

Да ли се ти слажеш са тим трендом?

И1: „Не, ако си паметан, паметан си и сналажљив било где, па тако и у Србији. " (мушко, 26, ЕТФ, Београд)

Трећи мотив који је навео испитаник као разлог због чега одлазак високообразованих из земље расте, указује на обесхрабрујућу последицу исељавања младих и нарочито образованих људи у иностранство, чиме је „створена атмосфера која потхрањује даља размишљања о одласку људи у иностранство“ (Болчић, 1995 према Деспић, 2015: 14) и чиме се „шири колективно осећање нестабилности и смањује поверење у успешност мера које друштво предузима у циљу санирања социјалних проблема“ (Гречић и сарадници, 1996 према Деспић, 2015: 14).

Када је реч о томе да ли мисле да постоји неко ко је посебно одговоран за то што млади одлазе из Србије, сви испитаници су навели одређеног актера као оног ко има пресудну одговорност. Поједини наводе да значајну одговорност има власт, други да је за то заслужан целокупан систем, родитељи, а неки сматрају да наведени чиниоци здружено утичу.

И1: „Па родитељи пре свега имају одговорност за то што млади одлазе из Србије, односно васпитање... онда касније школа, шира заједница али и држава. Менталитет је у Србији такав да држава треба да ти обезбеди посао.“ 
А мислиш да то не треба да буде тако?

И1: “Па мислим да се не треба ослањати само на то, уколико имаш предузетнички дух и мотивацију, можеш да успеш.“ (мушко, 27, ЕТФ, Београд)

Захваљујући развоју ИКТ, испитивани млади програмери имају више могућности и веће погодности у односу на друге младе високообразоване у Србији. Иако у односу на остале поседују одређене привилегије (високу плату, флексибилно радно време, аутономију на послу), ипак се може приметити да су свесни економске ситуације у овој земљи.

Значајно је навести и опажање да већина њих у погледу будуће каријере, исказује и жељу за покретањем сопственог бизниса.

И1: „Желео бих да лансирам неки свој производ, да имам своју причу, где бих могао да радим consulting, као што сада радим али на неком вишем нивоу, на нивоу архитектуре, система предлагања још сложенијих решења и слично." (мушко, 25, ПМФ, Београд)

И2: „Жеља ми је да радим на сопственом пројекту.“ (женско, 24, ФОН, Београд)

Додатна погодна ствар за Србију је и та што планирају да сопствени бизнис покрену управо у земљи у којој живе. Они испитаници који размишљају о томе да оду да би се додатно усавршили, а уједно планирају да се врате у Србију и оснују сопствену фирму, представљају добре примере транснационалног предузетништва. Ово је у складу са проценама да је највећи број транснационалих предузећа управо у делатности ИКТ (Павлов и др, 2013: 21).

\section{Дискусија}

С обзиром на то да је интервјуисано свега осам програмера старосне доби од 22 до 29 година, ауторка рада се ограничава у погледу закључака изведених из података добијених квалитатитвном анализом. Међутим, ипак су уочене одређене предности и недостаци прикривеног одлива мозгова, као и одређене последице по Србију уколико се овај проблем 
занемари. Главна предност прикривеног одлива мозгова јесте пре свега та што млади високообразовани нису физички емигрирали. Предност је и то што испитаници не планирају да се трајно преселе у иностранство, јер су, како наводе, задовољни својим послом и начином живота у Србији. Уколико би се одлучили да оду, то би било само привремено због жеље за додатним усавршавањем и стицањем искуства. Као предност се може узети и размишљање о будућој каријери, где испитаници, без обзира на то да ли имају жељу за привременим одласком или не, показују аспирацију да покрену сопствени посао управо у земљи у којој живе. Гледано из перспективе транснационалног предузетништва, треба имати у виду да програмери како одласком у развијене земље, тако и радом у иностраним фирмама усвајају нова знања и контакте на основу којих формирају своје мреже, што се такође може тумачити као предност. На овај начин отварају им се боље пословне могућности и формирају мреже, приватне и професионалне, што пружа могућност „да преко њих пренесу своје људске и друге ресурсе и на тај начин убрзају развој Србије и њено придруживање глобалним токовима“ (Павлов и др, 2013: 6). „Овај вид предузетника је успео да кроз развијене транснационалне мреже оствари пласирање робе на тржиште, рекламирање и стварање имиџа, остваривање кредибилитета и легитимитета“ (Павлов и др, 2013: 26).

С друге стране, недостатак прикривеног одлива мозгова у Србији је то што представља губитак квалитетне радне снаге за домаће тржиште. На тај начин, не само да су доприноси српском бруто домаћем производу смањени (у виду зараде радне снаге, док се ланац вредности налази ван Србије), већ запошљавање младих програмера у иностраним фирмама представља опортунитетни трошак у виду (не)запошљавања у домаћим фирмама које би могле да допринесу развоју домаћег ИКТ сектора, а тиме и развоју економије у Србији. Уједно, не треба занемарити могућност да се, услед различитих животних, али и друштвених околности, прикривени претвори у класичан одлив мозгова. 


\section{Закључак}

Прикривени одлив мозгова представља виртуелну емиграцију високообразоване радне снаге која захваљујући развоју ИКТ, пре свега интернету, ради за предузећа у страном власништву док живи у својој земљи. Анализа прикривеног одлива мозгова зависи пре свега од контекста у оквиру којег се проучава, што је у случају рада, Србија. Пре успостављања било каквих мера и акција за смањење ове појаве, потребно је разумети специфичност контекста. Тренутна слика Србије не одаје утисак да ће се дигитална трансформација брже развијати у скоријој будућности. Према проценама, за подршку локалним корисницима потребно је „скоро 20.000 ИТ стручњака, док их је у локалу тренутно запослено мање од 5.000“ (Матијевић, 2016). У раду је видљиво да постоје одређене промене, али динамика тих промена указује да ниједан од поменутих аспеката није наклоњен дигиталној трансформацији. Иако је познато да дигиталне технологије подстичу раст и развој, као и побољшање услуга, сматрамо да за њихов даљи развој неће бити довољно само повећати њихово усвајање. Због уочене повезаности која постоји између ране фазе развоја дигиталне трансформације и појаве прикривеног одлива мозгова у Србији, сви су изгледи да у догледно време прикривени одлив мозгова неће нестати, нити се смањити.

Парадоксално, иако је рана фаза дигиталне трансформације узрок појаве прикривеног одлива мозгова, управо би смањење прикривеног одлива мозгова могло да обезбеди даљи развој дигиталне трансформације у Србији. Први корак ка успостављању било каквих мера за сузбијање прикривеног одлива мозгова јесте пре свега разумевање ставова и мотива младих високообразованих људи у овој области. Опажања добијена истраживањем у овом раду, указују на то да дубља и шира анализа појаве прикривеног одлива мозгова може да пружи значајне смернице за проналажење и разумевање тих мотива. 


\section{Литература}

Despić, J. (2015). Migracije visokoobrazovanih lica iz Srbije od 1991. godine u Kanadu i Sjedinjene Američke Države. Doktorska disertacija, Univerzitet u Beogradu, Ekonomski fakultet.

Marjanović, D. (2015). Migracija radne snage i njen uticaj na demografsku sliku i tržište rada u Srbiji, istraživanje sprovedeno u okviru projekta „Uključivanje migracija u nacionalne razvojne strategije“.

Matijević, M. (2016). Može li domaći IT sektor do izvoza od milijardu evra do 2020? Beograd: Srpski IT osmatrač (SITO). https://www.sito.rs/moze-lidomaci-it-sektor-do-izvoza-od-milijardu-evra-do-2020/ (последњи пут приступљено 09.09. 2021.)

Pavlov, T., Jelačić, M., Jovanović, J., Milutinović, S., Despić Predojević, J. (2013). Preporuke za javne politike: transnacionalno preduzetništvo i uloga države. Beograd: Grupa 484.

Šolaja, M., Matijević, M. (2018). ICT in Serbia - At a Glance. Novi Sad: Vojvodina ICT Cluster. Преузето ca https://vojvodinaictcluster.org/wpcontent/uploads/2018/05/ICT-in-Serbia-\%E2\%80\%93-At-a-Glance-2018.pdf

Šolaja, M., Matijević, M. (2020). ICT in Serbia - At a Glance. Novi Sad: Vojvodina ICT Cluster. Преузето ca https://vojvodinaictcluster.org/ict-in-serbiaat-a-glance-2020-edition/

Rašević, M. (2016). Migracije i razvoj u Srbiji. Beograd: Međunarodna organizacija za migracije (IOM).

Tomanović, S. \& Stanojević, D. (2015). Mladi u Srbiji 2015. Beograd: FRIEDRICH EBERT STIFTUNG \& SeConS Grupa za razvojnu inicijativu. Преузето ca https://library.fes.de/pdf-files/bueros/belgrad/12065.pdf 


\section{Branka Matijević}

\section{Summary}

\section{Information Society Challanges: Hidden Brain Drain as The Specific Example of Labour Emigrations in Serbia}

COVID-19 pandemic put the spotlight on digital technologies causing the acceleration of digital transformation of world economies and societies. New digital workforce has two main characteristics: new jobs creation and rising mobility. However, shrinking of digital workforce (due to ageing populations) and insufficient number of workers with high-level digital skills, especially in EU, makes emigration still an active process. This paper analyzes the specific form of emigration process, named hidden brain drain, which is the side effect of both increased ICT usage (digital transformation) and growing deficiency of high-level digital skilled workforce.

Hidden brain drain is considered as a virtual emigration (in the sense of brain and skill emigration) of highly educated and skilled ICT workforce that, primarily thanks to the Internet, works for foreign companies while living in the home country.

For analysis of this phenomenon we interviewed 8 young (age from 22-29) respondents, highly educated programmers that live in Serbia and work for foreign companies. Semi-structured interview has proved to be a suitable method for collecting data and understanding respondents' attitudes and motives towards emigration and work for foreign companies.

Analysis lights up some interesting reasons that stand behind hidden brain drain phenomenon in Serbia and can be used as guidelines for further research. Surprisingly, young programmers in Serbia don't have the desire to emigrate, as they are surrounded by close people and have quality conditions for work and life. On the other hand, the proportional reduction of this digital labor force for the domestic market, as a new form of emigration, could lead to significant local labour market disruptions.

KEY WORDS: hidden brain drain; brain drain; ICT; digital transformation; Serbia 